\title{
South Sudan Negotiated Independence: A Critique of African Union's Role
}

By

\author{
Abubakar o. Sulaiman Phd. \& Agoha, Ifeanyi Chuckwu MSc.
}

\begin{abstract}
The emergence of South Sudan on the $9^{\text {th }}$ of July 2011 as the world's 195th independent State, 54th Member State of the African Union (AU) and 209th Federation of International Football Association member (FIFA) marks the final stage of a six year peace agreement ending decades of protracted civil war. According to BBC between 1983 and the peace agreement signed in January 2005, Sudan's civil war took nearly two million lives and left millions more displaced. It is reputed as Africa's longest-running civil war. The Sudanese civil war took roots from its colonial experience, which led to forceful cohabitation of Arabic (North) and African (South) ethnic groups into a single state.
\end{abstract}

Key Words: South Sudan, independence, conflict, resolution

\section{Introduction}

Multifarious factors accounted for the prolongation of the Sudanese civil war, chief among them are the ineffective and biased diplomatic interventions by intergovernmental bodies at the international, regional and sub-regional levels. One of the shortcomings of the defunct Organization of African Unity (OAU) was its deficient structural and institutional capacity to manage African conflicts, though no fault of the founding fathers because of the exigencies of the time, which was decolonization of the continent. The awareness of this structural and institutional defects inspired founding Member States of the African Union (AU) in 2002 to establish the Peace and Security Council (PSC) that will facilitate and fast-track the resolution of the protracted African conflicts; the Peace and Security Council (PSC) of the African Union entered into force on 26 December 2003, after being ratified by the required majority of Member States of the AU.

\footnotetext{
| ${ }^{1}$ University of Abuja-Nigeria.

2Independent National Electoral Commission Abuja-Nigeria.
} 


\subsection{South Sudan State: A Product of Conflict Resolution}

Africa remains one of the most important and virile laboratories for the production of knowledge in ethnicity and its management due to the seemingly intractable conflicts that ravage the continent. This is in view of the widely held, but partly misleading belief that most political conflicts in Africa are ethnic. To this end, Commentators and analysts have argued that the diversity, complexity and intractability of these conflicts have posed some of the greatest challenges to the theory and practice of conflict management and resolution in Africa. It is against this background that the efficacy of the Peace and Security Council (PSC) of the African Union will be critically contextualized in the struggle for the South Sudan Negotiated Independence.

Though the South Sudan attained statehood through the process of conflict resolution, the process was fraught with various challenges. The greatest challenge faced by the South Sudan in its struggle for independence happened to be incumbent President of Sudan Omar al-Bashir, but for perceived possible US military attack he would have continued to refuse to sit and dialogue with the rebels. Based on the fact extracted from the extant literature we can posit that the change in the attitude of Omar al-Bashir paved the way for the resolution of the Sudanese war.

\section{The Road to Independence}

Young John (2007) in his work titled Sudan IGAD Peace Process: An Evaluation segments the Sudan Inter-governmental Authority on Development (IGAD) peace path into two. According to him, the first Sudan IGAD Peace Initiative was between September 1993 and May 2002; while the second was within May 2002 to January 2005. According to Young, the failure of various efforts laid the basis for the region to take up the gauntlet, but first a suitable mechanism had to be established, and what is significant here is that the impetus came from outside the region. He argues that the formation of the Inter-Governmental Authority on Drought and Development (IGADD), the fore-runner to IGAD, was largely due to pressure from aid agencies and international donors, while its subsequent assumption of responsibilities in the fields of peace and security followed new thinking on the role of regionalism and regional cooperation in safeguarding the international order.

He went on to state that in the wake of the failed Nigerian efforts, IGADD launched a peace initiative at its Addis Ababa summit of 7 September 1993 and a Peace Committee made up of the heads of state of Ethiopia, Eritrea, Uganda, and Kenya was established with President Daniel Arap Moi serving as chairman. The mediation process was handled by a Standing Committee made up of the foreign ministers from the same countries and chaired by Kenya. In addition, the Friends of IGADD was formed by leading Western countries and it promised support for IGADD's peace keeping role.

It was against this background that Sudan's President Omar Bashir proposed that IGADD take up the peace process. The reasons for Bashir's proposal included the desire to pre-empt any UN initiative, fear that in the absence of a viable peace process that US military engagement under way in Somalia could spread to Sudan, and because his government had provided support to the Ethiopian and Eritrean rebel groups in the 
period immediately prior to their capture of state power he anticipated it would receive a fair hearing from them.

Discussing the second IGAD Peace Initiative (May 2002 to January 2005) in the opinion of Young (2007) came up the issue of the frustration with the lack of progress in the peace process, growing US interest in Sudan as a result of the increasing profile of Sudan's civil war in domestic politics and its perceived link to American security, and the rejuvenation of the peace process are linked and provided the stimulus for the second and successful IGAD peace initiative. It is imperative to note that many people point to the terrorist attack on 11 September 2001 to explain heightened US interest in Sudan, but the American bombing of the Khartoum Al-Shiffa Pharmaceutical Plant in August 2000 on the basis of faulty intelligence information that it was producing chemical weapons made clear a much earlier American concern with the country. Moreover, President George W. Bush's appointment of special peace envoy, Senator Danforth, five days before the $11^{\text {th }}$ September attack, demonstrated growing US concern about the faltering Sudan peace process.

We have in this segment discussed the contents and context within which the Comprehensive Peace Agreement (CPA) 2005 was birthed, the context indicated the ripeness of the age long conflict that needed to be resolved. Our analysis has also shown that the US played an influential role in ensuring that the IGAD succeeded with the peace process it had facilitated. What we are saying in essence is that the international context or prevailing situations between 2002 and 2005 (in which US was the Chief actor), also contributed to the successful making of the CPA in 2005.

\subsection{South Sudan Emergence and the Role of African Union: A Critique}

It is germane to note that the AU was not part of the making of the CPA (2005) which defined the terms and conditions for the conduct of referendum and the declaration of South Sudan independence. However the AU played prominent role in facilitating the implementation of the CPA. Though the independence of the South Sudan, on the surface indicates successful implementation of the CPA, but beyond the surface, there are other un-resolved issues or 'unfinished business of AU that may put to test its much mouthed facilitation of the CPA.

These unresolved issues relate to disagreement over sharing of oil revenue between Sudan and South Sudan. The oil-endowed South Sudan is a land-locked country that depends on Sudan for the infrastructure to export its oil (pipelines, refineries and Red Sea port are in the north). Transit charges on oil from South Sudan to the Sea port in Sudan are some of the issues that are (plausibly not envisaged by drafters of CPA or tokenized by AU during implementation stage) discrediting the intervention of $\mathrm{AU}$ in the implementation of CPA. The second issue that has watered down the success of the AU relates to contested status of three Border States. These three states have been termed the Three Areas, by analysts. They are: Abyei, Southern Kordofan and Blue Nile.

For the purpose of analytical clarity we shall start with a section where we shall discuss the multi-lateral processes that led to the making of the CPA, with a view of depicting the prominent role played by the IGAD on one hand and the non-visibility of the AU in the process of making the CPA in 2005. The next section will be devoted to the analysis of the role AU played in South Sudan's negotiated independence through its 
structure, the Peace and Security Council and its African Union High Level Implementation Panel on Sudan (AUHIP). Thereafter we shall discuss the two outstanding issues in the implementation of the CPA (oil revenue sharing and the three Border States). We shall discuss each of them in different sections respectively.

\subsection{Multi-lateral Processes that Produced CPA (2005)}

It must be stated up-front that the Inter-governmental Authority on Development (IGAD) played a leading role in the making of the CPA; while the AU has played and is still playing dominant role in the implementation of the CPA. It was the IGAD that facilitated the process of making the CPA; and after the signing of the CPA in 2005, the AU has assumed active role in its implementation.

The Intergovernmental Authority on Development (IGAD) was formed in 1986 with a very narrow mandate around the issues of drought and desertification. Member States are: Djibouti, Somalia, Eritrea, Sudan, Ethiopia, Uganda and Kenya. Since its formation and especially in the 1990s, IGADD became the accepted vehicle for regional security and political dialogue. The founding members of IGADD decided in the mid-1990s to revitalize the organization into a full-fledged regional political, economic, development, trade and security entity similar to SADC and ECOWAS. The IGADD Heads of State and Government met on 18 April 1995 at an Extraordinary Summit in Addis Ababa and resolved to revitalise the Authority and expand its areas of regional co-operation. On 21 March 1996, the Heads of State and Government at the Second Extraordinary Summit in Nairobi approved and adopted an Agreement Establishing the Intergovernmental Authority on Development (IGAD).

In April 1996 on the recommendation of the Summit of the Heads of State and Government, the IGAD Council of Ministers identified three priority areas of cooperation which are: (1.) Conflict Prevention, Management and Resolution and Humanitarian Affairs; (2.) Infrastructure Development (Transport and Communications). (3.) Food Security and Environment Protection. (IGAD Official Publication, not dated, 1-2)

Basically the IGAD aims to expand the areas of regional co-operation, increase the members' dependency on one another and promote policies of peace and stability in the region in order to attain food security, sustainable environment management and sustainable development. To achieve these aims, IGAD set up organs viz: Assembly of Heads of State and Government; which meet at least once a year, and is the supreme organ of the Authority; Council of Ministers that is composed of the Ministers of Foreign Affairs and one other focal minister designated by each member state. The Council meets at least twice a year. Another important organ of IGAD is the Committee of Ambassadors which comprise the Ambassadors or Plenipotentiaries of IGAD member states accredited to the country of IGAD's headquarters. The Committee of Ambassadors advises and guides the Executive Secretary on the promotion of his efforts in realising the work plan approved by the Council of Ministers and on the interpretation of policies and guidelines which may require further elaboration.

It is germane at this point to reiterate that much of IGAD's attention is directed at peace efforts in Somalia and the Sudan. During 1994, IGADD started to undertake conflict management tasks when the Authority hosted and facilitated negotiating sessions 
between the Sudanese government in Khartoum and the rebel forces from southern Sudan in an attempt to end the civil war. The Sudan peace process, chaired by Kenyan President Moi, brought IGADD into the limelight and revitalised the organisation. This led to the change in name in April 1996 and the creation, within the new Intergovernmental Authority on Development (IGAD), of a department for conflict management. Article 18 of the agreement establishing IGAD states that member states shall act collectively to preserve peace, security and stability which are essential prerequisites for economic development. (IGAD, Official Publication not dated)

The original Ministerial Subcommittee has since been replaced by a permanent secretariat on the Sudan Peace Process, based in Nairobi, to mount a sustained effort to resolve the conflict. President Moi appointed Lieutenant-General Lazarus Sumbeiywo as special envoy to Sudan. The first round of talks held under this arrangement began in February, 2000. In July 2002, talks in Machakos, Kenya resulted in the Sudanese Government and the Sudanese People's Liberation Army (SPLA) signing the Machakos Protocol. The protocol provides for a six-month "pre-interim period" during which hostilities should cease and a formal ceasefire should be established as soon as possible. During a subsequent six year "interim period", the ceasefire should be maintained and Sharia law should not be applied in the south during that period. After six years, a referendum on southern self-determination should be held. (IGAD, Official Publication not dated)

A second round of talks was held in Machakos during August-September 2002, which attempted to negotiate a ceasefire. However, the talks broke down on 3 September when the Khartoum government recalled its delegation for "consultation" over the SPLA capture of the strategic town of Torit. Talks resumed in Machakos in October 2002. On 15 October, a Memorandum of Understanding was signed which agreed to a cessation of hostilities for the duration of talks. On 26 October the Khartoum Government and the SPLM/A agreed to grant unimpeded access to civilians for humanitarian agencies. (IGAD, Official Publication not dated, 5) The weaknesses of the IGAD mediation include:

- Lack of inclusivity of interested parties in southern Sudan, notably civil society and other political parties, and at the national level for a peace process that claimed to be comprehensive. The result is an agreement that is effectively a bilateral arrangement between the SPLM and the NCP for which most people in Sudan feel no sense of ownership.

The peace process never developed trust and understanding between the parties, and in its absence and the failure to commit to wide-ranging reconciliation, the mediation followed Western practice and emphasised legal requirements and time-tables. But the great number of bodies and commissions formed to regulate, monitor, and adjudicate disputes have not managed to overcome the lack of trust between the SPLM and the Government of Sudan, and as a result the implementation of the agreement is far behind schedule.

- The elitist approach of the mediation was also manifest in its disdain for the media. Instead of viewing the media as a partner in the peace process, a valued critic, 
and a crucial instrument with which to engage the Sudanese public and provide a measure of accountability, it was treated as an enemy and a threat.

- The lack of inclusivity of the peace process means that the Sudanese people can only pass judgement on the CPA through national elections, but the elections have been delayed and the difficulties in demarcating the north-south border and ending the conflict in Darfur may result in a further postponement. In addition, the development of a democratic culture conducive for the holding of fair elections has not been permitted to emerge in either north or south Sudan where security regimes dominate. Lastly, the National Assembly has passed legislation that prohibits parties participating in the national election unless they endorse the $\mathrm{CPA}$, thus precluding a negative assessment of the agreement.

- The narrow focus of the mediation and the emphasis on reaching an agreement meant its implications were not fully appreciated. Thus the agreement to dissolve OAGs threatened to unleash a war between the SPLA and the South Sudan Defence Force, while the power sharing arrangement which gave the SPLM and the NCP the lion's share of state power undermined efforts to reach a settlement in Darfur and have encouraged secessionist sentiments in the country.

- While international engagement in the peace process is necessary, the mediation failed to appreciate that this engagement posed a threat to the sovereignty of Sudan and the IGAD region. The conclusion of the US and its allies that their security and the 'war on terror' necessitates heightened military and diplomatic involvement in the Horn raises fears that the region could again - as it was during the Cold War - become a focus of competition and conflict for external interests.

- $\quad$ Although never stated, the mediation was carried out on the basis of a narrow model which focused on ending the violence (many respondents referred to it as an extended cease-fire), instead of laying the basis for a sustainable and comprehensive peace in the south and the country at large. (Young John, 2007)

A plethora of peace agreements that have resulted from various negotiations facilitated by local and international third parties includes amongst others; the 1986 Koka Dam Agreement; the 1987 National Islamic Front Sudan Charter; the 1992 Abuja Peace Conference Communiqué; the 1993 Abuja Peace Conference Statement; the 1994 Declaration of Principles; the 1997 Sudan Peace Agreement; the 1997 Nuba Mountains Peace Agreement; the 1997 Fashoda Peace Agreement; the 1999 Wunlit Covenant; the 1999 Homeland Call; the 1999 Blue Nile Peace Agreement; the 2000 Liliir Peace Conference; the 2000 Libyan-Egyptian Peace Proposals; and the 2001 Comboni Missionaries Declaration. All these preceded the making of the 2005 Comprehensive Peace Agreement (CPA) on the basis of which referendum was conducted and independence attained on January 9th 2011 and July 9th 2011 respectively. The implication of this is that, the principles, provisions and agreements contained in the CPA, were not all reached or initiated in 2005; in point of fact, some of the principles in the above listed peace agreements were incorporated into the CPA in 2005. 


\section{The Role of AU in South Sudan's Negotiated Independence}

The AU through its African Union High Level Implementation Panel on Sudan (AUHIP) led by former President Thabo Mbeki has been and is still involved in the implementation of the CPA. At its 207th meeting, held at the level of Heads of State and Government, in Abuja, Nige ria, on 29 October 2009, Council authorized the establishment of the AU High Level Implementation Panel (AUHIP) on Sudan. Basically the AU supervised the successful conduct of the referendum and facilitated the process leading to the declaration of independence in the same year. The AUHIP has since the attainment of independence by South Sudan been involved in the ensuring that the two countries peacefully resolve other post secession issues.

\subsection{Critique of AU Role in South Sudan's Negotiated Independence}

Factually, when the series of negotiations that led to the making of the CPA 2005 started the African Union was not in existence and when it was eventually set up in the year 2002, the AU was still at the infancy when the CPA was signed in 2005. At any rate, as already indicated at the introduction section the AU did not played any significant role in the multifarious processes leading to the making of the CPA; but the Union played a dominant role in ensuring that the CPA was successfully executed.

As indicated above the African Union (AU) played a key role in the successful implementation of the Comprehensive Peace Agreement. To be sure, the AU derived its mandate to intervene in regional conflicts from the United Nations Charter, Chapter 8, which dwells on Regional Arrangements; in effect this Article empowers nations to put up regional peace mechanisms in order to further promote world peace. Article 52 (1) of the UN Charter states:

Nothing in the present Charter precludes the existence of regional arrangements or agencies for dealing with such matters relating to the maintenance of international peace and security as are appropriate for regional action provided that such arrangements or agencies and their activities are consistent with the Purposes and Principles of the United Nations.

The AU through its African Union High Level Implementation Panel on Sudan (AUHIP) led by former President Thabo Mbeki, actively consulted with the Parties in order to clear inevitable bottle necks in the process of implementing the Comprehensive Peace Agreement (CPA). Some of the rough edges of the CPA that the AU has been smoothening are issues of citizenship, oil exportation, and other allied issues. It can be argued that, the implementation of the CPA has been going smoothly under the watch of the African Union High Level Implementation Panel on Sudan (AUHIP); however in less than a year of national independence it appears that attainment of South Sudan independence was an unfinished business, that will still require months or years to be finally finished by the AU. Recently, the chairperson of the African Union (AU) Commission urged both Khartoum and Juba to respect the provisions of the Memorandum of Understanding $(\mathrm{MoU})$ on non-aggression and cooperation signed in Addis Ababa, Ethiopia not too long ago; the said MoU is an addendum to the CPA. In 
the meantime, the two countries have been admonished to refrain from actions or statements that are likely to complicate the post-succession negotiations under the mediation of the AU High Level Implementation Panel (AUHIP).

The AU chairperson reportedly requested the two countries to demonstrate the required spirit of compromise and mutual accommodation, as well as to extend unreserved cooperation to the AU High Level Implementation Panel (AUHIP), in the conduct of its facilitation role. The AU, its Chairperson reiterated, will continue to closely follow the negotiations between Sudan and South Sudan on their post-secession relations until a successful conclusion is reached. He also stated that the African Union will continue to monitor the situation on the ground, with a view to keeping the Peace and Security Council (PSC) fully informed of the implementation status of the Memorandum of Understanding, especially in view of the continued allegations and counter allegations of incidents, bombardments and troop movements along the common border.

For our purpose, we can characterize the role played by the IGAD and the AU as that of exchange of baton, for where the IGAD had stopped the AU took off. This is because since the AU has been playing leading role in the process of implementing the CPA (2005), the IGAD had taken backward step on the issue of implementation of the $\mathrm{CPA}$; it has given the AU the space to contribute its quota to peace process in Sudan. In critiquing the role of the AU therefore, we can say that the Union, though a late comer to the Sudanese peace process have achieved a lot in its bid to prove to the entire world that the AU could be rightly regarded by visitors as very attractive.

The Continental body made giant and great strides in managing the implementation of the CPA which culminated in helping the Sudanese in organizing a successful selfdetermination referendum in South Sudan and eventual independence of South Sudan.

It is pertinent to note that the AU still has a lot more to do because there are a number of issues of contention remaining between North and South Sudan, including unresolved issues of the Comprehensive Peace Agreement. A lot needs to be done to sort out the post-secession issues and ensure that the two countries adhere to and implement their decisions of two viable States living side by side and cooperating on issues of common concern..

In the view of the above, the paper canvasses the view that the AU needs to initiate post-independence bilateral agreement between Sudan and South Sudan in order to address the unfinished business which the CPA 2005 failed to foresee and checkmate. There are other issues in the pack of the unfinished business of the attainment of independence. The two countries need to see each other as Siamese twins that cannot afford to live separately.

Prior to the formation of the African Union (AU) in 2002, the defunct Organization of African Unity $(\mathrm{OAU})$ did not have structures, capacity nor coordinated approach in managing African conflict; as a result, many conflicts in Africa like that of Somalia were managed by the UN; while the OAU took the back seat. The realization of deficient conflict management structures in the regional body inspired member States of AU, the OAU successive body, to establish both Peace and Security Council and Peace and Security Commission respectively for the purpose of managing and resolving African conflicts. 


\section{Recommendations}

Arising from the foregoing the study makes the following recommendations:

That further study should examine the extent to which finance could affect the capabilities of the AU to manage African conflicts.

That other scholar should attempt to juxtapose the role played by both IGAD and AU on Sudanese civil war.

That Peace and Security Council of the AU should be strengthened so that intractable conflicts in Africa such as that of Somalia will be brought to an end.

That the AU should set in place its ad hoc interventionist body with a permanent Sudan/South Sudan commission that will manage conflicts between the two countries on sustainable basis.

The IGAD and the AU should convene a conference where other post-secession relationships between the two countries will be addressed and settled conclusively.

\section{References:}

Ortega, M. 2001, Military Intervention and the European Union, Institute for Security Studies of Western European Union, Chaillot Paper 45, ICISS, 2001, The Responsibility to Protect, Report of the International Commission on Intervention and State Sovereignty

Petersen, J. 1976, "Economic Interests and U.S. foreign policy in Latin America: An empirical approach." In: Raichur, S. and Liske, C. (eds.). The Politics of aid, trade and investment, New York: Russell Sage,

Luard, E. 1988, Conflict and Peace in the Modern International System, London: Macmillan,

Stern, E.P. 1977,The Limits of Military Intervention. London: Sage Publications,

Regan, P.M. 1996, Conditions of Successful Third Party Intervention in Intrastate Conflicts. Journal of Conflict Resolution, Vol.40, No.2

Ramsbotham, O.P. and Woodhouse, T. 1996, Humanitarian Intervention in Contemporary Conflict: A Reconceptualisation. Cambridge: Polity Press.

Connaughton, R. 1992, Military Intervention in the 1990s: A New Logic of War. New York: Routledge

Jackson, R. 2000, The Global Covenant: Human Conduct in a World of States.

New York: Oxford University Press.

Griffin, M. 2000. Where Angels Fear to Tread: Trends in International Intervention. Security Dialogue, Vol.31, No.4,

Gow, J. 2000. “A Revolution in International Affairs” Security Dialogue, Vol.31,

No.3,

Matlary, J.H. 2004 .The Legitimacy of Military Intervention: How Important is a UN Mandate? Journal of Military Ethics, Vol.3, No.2

Krain, M. 2005. International Intervention and the Severity of Genocides and

Politicides. International Studies Quarterly, Vol.49,

Rothchild, D. 2006, The Logic of a Soft Intervention Strategy: The United States and Conflict Conciliation in Africa. International Negotiation, Vol.11,

Gegout, C. 2005, Causes and Consequences of the EU's Military Intervention in the Democratic Republic of Congo: A Realist Explanation. European Foreign Affairs Review, Vol.10,

Smith, G. and Hay, J. 1999, "Canada and the Crisis in Eastern Zaire." In: Crocker, C.A., Hampson, F.O. and Aall, P. (eds.) Herding Cats: Multi-Party Mediation in a Complex World. Washington, DC: USIP Press, 
Wheeler, N.J. 2000, Saving Strangers: Humanitarian Intervention in International Society. Oxford: Oxford University Press,

Von Hippel, K. 1995, The Non-Interventionary Norm Prevails: An Analysis of Western Sahara. The Journal of Modern African Studies, Vol.33, No.1.

Cilliers, J. and Sturman, K. 2002, The Right Intervention: Enforcement Challenges for the African Union. African Security Review,

Somerville, K. 1990, Foreign Military Intervention in Africa. London: Pinter Publishers,

Williams, P.D. 2007, From Non-intervention to Non-indifference: The Origins and Development of the AfricanUnion's Security Culture. African Affairs, Vol.106, No.423.

Malan, M. 1997, The Principle of Non-interference and the future of Multinational Intervention in Africa. African Security Review, Vol.6, No.3,

Gillespie, T. R. 1993, Unwanted Responsibility: Humanitarian Military

Intervention to advance Human Rights. Peace \& Change, Vol.18, No.3, July

Neethling, T. 2006, Working Towards an African Peacekeeping Capability: Key Issues, Challenges and Dilemmas in Darfur. South African Journal of Military Studies, Vol.34, No.2.

Mathiasen Flemming (2006) The African Union and Conflict Management, a Strategy Research Project, submitted to the U.S. Army War College, Pennsylvania: U.S. Army War College.

Boutros-Ghali, Boutros. 1992. An agenda for Peace: Preventive diplomacy, peacemaking, and peace-keeping. New York: United Nations.

Patrick M. Regan 1996, Conditions of Successful Third-Party Intervention in Intrastate Conflicts, The Journal of Conflict Resolution, Vol. 40, No. 2 (Jun., 1996), pp. 336-359: Sage Publications, Inc. Stable URL: http://www.jstor.org/stable/174356 Accessed: 14/05/2010 12:21.

Bercovitch, Jacob. 1989. International dispute mediation: A comparative and empirical analysis. In Mediation research, edited by K. Kressel and D. G. Pruit. San Francisco: Jossey-Bass.

Bercovitch, Jacob, and J. Rubin, eds. 1994. Mediation in international relations. London: MacMillan.

Carment, David. 1993. The international dimensions of ethnic conflict: Concepts, indicators, and theory. Journal of Peace Research 30(2):137-50.

Damrosch, Lori Fisler, ed. 1993. Enforcing restraint: Collective intervention in internal conflicts. New York: Council on Foreign Relations.

Gottlieb, Gidon. 1993. Nation against state: A new approach to ethnic conflicts, the decline of sovereignty, and the dilemmas of collective security. New York: Council on Foreign Relations.

Gurr, Ted Robert. 1993. Minorities at risk: A global view of ethno-political conflicts. Washington, DC: United States Institute for Peace. - 1994. Peoples against states: Ethno political conflict and the changing world system. International Studies Quarterly 38(3):347-78.

Gurr, Ted Robert, and Barbara Harff. 1994. Ethnic conflict in world politics.

Boulder, CO: Westview. Horowitz, Donald. 1985. Ethnic groups in conflict.

Berkeley: University of California Press.

Patchen, Martin. 1988. Resolving disputes between nations: Coercion or concilliation? Durham, SC: Duke University Press. Pearson,

Frederick S. 1974. Foreign military interventions and domestic disputes, International Studies Quarterly 18(3):259-89.

AlertNet. 2012. Sudan conflicts Brutal wars in Africa's biggest country, available at:http://www.trust.org/alertnet/crisis-centre/crisis/sudan conflicts?gclid=CPOTx63PlbACFUrP3wodmBHv0g

Mathiasen Flemming 2006 The African Union and Conflict Management, a Strategy Research Project, submitted to the U.S. Army War College, Pennsylvania: U.S. Army War College. 